\title{
Prevalence of Chlamydia pneumoniae antibodies in patients with acute respiratory infections in Israel
}

\author{
M Ben-Yaakov, Z Lazarovich, S Beer, A Levin, I Shoham, I Boldur
}

\begin{abstract}
Aims-To evaluate the prevalence of antibodies to Chlamydia pneumoniae (TWAR) in relation to other aetiological agents of acute respiratory infections in Israeli patients.

Method-Serum samples from 604 patients (183 children and 421 adults) were collected over three years. Antibodies to $C$ pneumoniae, $C$ trachomatis, and Legionella sp were evaluated using the microimmunofluorescence (MIF) assay. Antibodies to Mycoplasma pneumoniae were detected using the Serodia Myco II test.
\end{abstract}

Results-Antibodies to TWAR were detected in $319(51 \cdot 3 \%)$ sera. Twenty one patients had MIF results indicative of recent infection. TWAR prevalence and antibody titres in children (aged 1-10 years) were low, gradually increased in teenagers (11-18 years), and were highest in adults and elderly patients. In contrast to the consistently noted TWAR antibody prevalence and serological evidence of recent infection during the study period, a significant decrease in those variables was recorded for $C$ trachomatis. Six patients had serological evidence of recent infection with both $C$ pneumoniae and $C$ trachomatis. The presence of antibodies to Mycoplasma pneumoniae and Legionella sp was tested in 473 of the patients; 29 had antibodies to $M$ pneumoniae and 23 to Legionella sp. Six patients (including five children) had serological evidence of recent infection with $M$ pneumoniae and four with Legionella sp.

Conclusion-C pneumoniae should be considered in patients with acute respiratory diseases. MIF is the preferred method for monitoring the presence of antibodies to this organism.

Department of Microbiology, Assaf Harofeh Medical Center, Zerifin, Israel $M$ Ben-Yaakov Z Lazarovich A Levin I Shoham I Boldur

Pulmonary Allergic Service; Shikma Children Clinic, Bat Yam, Israel

$\mathrm{S}$ Beer

Correspondence to: M Ben-Yaakov

Accepted for publication 7 October 1993 niae, Legionellae, and viruses, are the aetiological agents of atypical pneumonia.

Seroepidemiological studies from different areas of the world indicate that TWAR is distributed worldwide. ${ }^{2-13}$ Antibodies to it are rare before the age of 5 years. An increase in seropositivity is observed with age, and it is reported that by the age of 13-17 a third to three quarters of teenagers have antibodies to TWAR. ${ }^{25791112}$ Prevalence then further increases to $40-80 \%$ and persists into old age. ${ }^{211-13}$

This three year study was undertaken to investigate the prevalence of $C$ pneumoniae antibodies in Israeli patients, as well as the prevalence of antibodies to other microorganisms associated with lower respiratory tract infections like $M$ pneumoniae, Legionella and $C$ trachomatis.

\section{Methods}

Serum samples taken between June 1989 and May 1992, from 183 children up to the age of 18 years and 421 adults with undefined acute respiratory diseases, mostly atypical pneumonias, were sent to us for chlamydial serodiagnosis. A second serum sample was collected from 18 patients three weeks after the first sample, while only one serum sample was available from 586 patients. The sera were tested immediately and stored at $-20^{\circ} \mathrm{C}$ until further use.

\section{ANTIBODIES TO CHLAMYDIA}

MIF test

The prevalence of antibodies to $C$ pneumoniae was determined using formalin fixed elementary bodies of $C$ pneumoniae TWAR (Washington Research Foundation, Seattle, USA) as antigen. The antigen reacted with monoclonal antibody specific for $C$ pneumoniae (a gift from Dr Persson, Sweden) but not $C$ trachomatis. The sera were diluted twofold starting at 1 in 16 . Specific chlamydial antibodies were measured using fluorescein isothiocyanate (FITC) conjugated sheep anti-human immunoglobulin (Institut Pasteur, France) and positive sera of $\geqslant 1 / 16$ were further analysed using FITC conjugated goat antihuman IgG and IgM (Institut Pasteur, France). Antibodies to $C$ trachomatis were detected using formalin fixed elementary bodies of $C$ trachomatis L2/434 as antigen and FITC conjugated anti-human Ig, IgG, IgA, and IgM.

A titre of $\geqslant 1 / 512$ in the IgG fraction, $\geqslant 1 / 16$ in the IgM fraction, or a four-fold titre change in the IgM or IgG antibodies (seroconversion) was considered indicative of recent infection. Chlamydia antibody titres of $1 / 16$ to $1 / 256$ in the IgG fraction were considered indicative of past infection. Sera were tested for the presence of IgM antibodies after 
a strip-treatment with reagents from the IPAzyme chlamydia "true" IgM kit (Savyon Diagnostics, Israel) to avoid false results introduced by the presence of IgG or rheumatoid factor (RF) in the serum. ${ }^{14}$

\section{IPAzyme assay}

The IPAzyme immunoperoxidase assay was used to detect chlamydial IgG, IgA, and IgM antibodies, according to the manufacturer's instructions. IgG antibodies at a titre of $\geqslant 1 /$ 128 , an IgM titre of $\geqslant 1 / 16$, and an IgA titre of $\geqslant 1 / 16$ were considered indicative of recent infection. A titre of $1 / 64$ in the IgG fraction was considered indicative of past infection.

\section{Antibodies to Legionella sp}

Antibodies to different serogroups of Legionella sp were detected using the indirect immunofluoresence test, as described before. ${ }^{15}$ Nine groups of formalin fixed Legionella $s p$ (pooled or single) served as antigens:

pool I-L pneumophila serogroups 1-4; pool II-L pneumophila serogroups 5-6; pool III-L pneumophila serogroups 7-10; pool IV-L longbeachae serogroups 1-2; pool V-L bozemanii serogroups 1-2;

pool VI-L feeleii, $L$ wadsworthi, $L$ jordanis,

\section{L dumoffii} L oakridgensis

$L$ gormanii

$L$ micdadei

A titre of $\geqslant 1 / 256$ in the IgG fraction or a lower titre, together with IgM antibody of $\geqslant 1 / 64$ was considered indicative of recent infection. ${ }^{16}$

\section{Antibodies to $M$ pneumoniae}

Antibodies to $M$ pneumoniae were detected using the Serodia Myco II particle agglutination test kit (Fujirebio Inc, Japan). ${ }^{17} 18$ A titre of $\geqslant 1 / 320$ was considered indicative of recent infection.

\section{Rheumatoid factor}

The presence of RF was detected using the Arthi Slidex technique (BioMèrieux, France).

The significance of data was determined using the $\chi^{2}$ test. A probability value (p) of $<0.05$ was considered significant.

\section{Results}

PREVALENCE OF ANTIBODIES TO $C$ pneumoniae The presence of IgG antibodies to $C$ pneumoniae was detected by the MIF test in 319 $(51.3 \%)$ of the 622 tested sera with titres ranging from $1 / 16$ to $\geqslant 1 / 512$ (table 1 ). Using the IPAzyme assay, 66 out of $187(35.3 \%)$ sera with anti-TWAR MIF titres of $\geqslant 1 / 64$ and 93 out of $435(21.4 \%)$ sera with antiTWAR MIF titres of $<1 / 64$ showed a positive reaction. All MIF IgG reactive sera and 175 negative sera were tested for IgM class antibodies in the MIF test. Fifteen patients with an IgG reaction had a positive IgM reaction, 12 patients had an IgM titre of $1 / 16$, and three patients had a titre of $1 / 32$, but no correlation with IgG titres was noticed.

Twenty one adults had MIF results indica-
Table 2 Age dependent prevalence of $\operatorname{Ig} G$ antibodies to $C$ pneumoniae

\begin{tabular}{clcl}
\hline Age (years) & No of patients & No (\%) positive & $M G T$ \\
\hline$<1$ & 57 & $16(28)$ & $1 / 52$ \\
$1-5$ & 39 & $8(21)$ & $1 / 22$ \\
$6-10$ & 16 & $4(25)$ & $1 / 32$ \\
$11-18$ & 12 & $4(33)$ & $1 / 32$ \\
$19-30$ & 25 & $11(44)$ & $1 / 75$ \\
$31-50$ & 29 & $16(55)$ & $1 / 101$ \\
$51-70$ & 44 & $29(66)$ & $1 / 91$ \\
$\geqslant 71$ & 32 & $22(69)$ & $1 / 11$
\end{tabular}

Positive $=$ titre of $\geqslant 1 / 16 ; \mathrm{MGT}=$ mean geometric titre of positives

tive of recent infection. Of the 586 patients with only one available serum sample, 12 had a positive IgM titre (1/16-1/32), and four had a high IgG titre $(\geqslant 1 / 512)$, as the indicative criteria for their recent infection with $C$ pneumoniae. Of the 18 patients with two available serum samples, two with early negative or low positive sera had seroconverted. For three patients with an early positive serum (IgM titre 1/16-1/32 and/or an IgG titre of 1/512) the diagnosis was confirmed by testing the second serum sample. (A fourfold titre change and/or an IgG titre of $\geqslant 1 / 512$.)

AGE RELATED PREVALENCE OF IgG CLASS ANTIBODIES TO $C$ pneumoniae

The prevalence of antibodies to $C$ pneumoniae in the sera of patients whose age was known was evaluated using the MIF test (table 2). There was a significant difference $(p<0.05)$ in prevalence as well as in mean geometric titre (MGT) between children $(n=124)$ and adults $(n=130)$, but differences within the groups were not significant $(p>0.05)$.

An analysis of the titres showed that 66 children out of 183 had moderate MIF titres of 1/16-1/256, while 234 out of 421 adult patients had titres of $1 / 16-1 / 256$ and seven had IgG titres of $\geqslant 1 / 512$ (figure).

PREVALENCE OF ANTIBODIES TO $C$ pneumoniae AND $C$ trachomatis DURING THE STUDY PERIOD A comparison of the three study years for prevalence of antibodies to $C$ pneumoniae and $C$ trachomatis showed an even distribution of seropositive results for $C$ pneumoniae, but a decline for $C$ trachomatis (table 3 ). This decline was significant $(p<0.05)$. A parallel decline was observed in the prevalence of

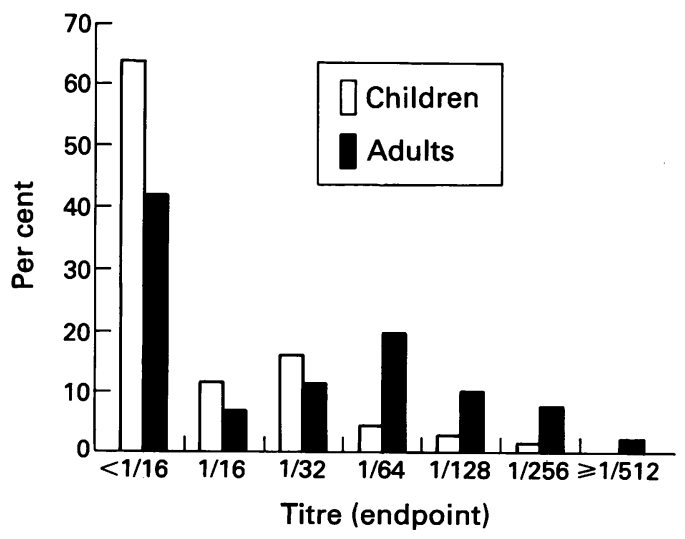

TWAR IgG endpoint titres in 183 children and 421 adults with acute respiratory infections measured by the MIF test. 
Table 3 Comparison of prevalence of antibodies to $C$ pneumoniae and $C$ trachomatis during study period

\begin{tabular}{|c|c|c|c|c|c|}
\hline \multirow[b]{2}{*}{$\begin{array}{l}\text { Study } \\
\text { period }\end{array}$} & \multirow[b]{2}{*}{ No } & \multicolumn{2}{|c|}{$C$ pneumoniae } & \multicolumn{2}{|c|}{$C$ trachomatis } \\
\hline & & $\begin{array}{l}\text { Seropositive } \\
\text { No (\%) }\end{array}$ & $\begin{array}{l}\text { Recent infection } \\
\text { No (\%) }\end{array}$ & $\begin{array}{l}\text { Seropositive } \\
\text { No (\%)- }\end{array}$ & $\begin{array}{l}\text { Recent infection } \\
\text { No (\%) }\end{array}$ \\
\hline $\begin{array}{l}\text { I } \\
\text { II } \\
\text { III }\end{array}$ & $\begin{array}{r}76 \\
164 \\
364\end{array}$ & $\begin{array}{l}43(56 \cdot 6) \\
81(49 \cdot 4) \\
172(47 \cdot 5)\end{array}$ & $\begin{array}{l}1(1 \cdot 3) \\
6(3 \cdot 7) \\
14(3 \cdot 9)\end{array}$ & $\begin{array}{l}44(58 \cdot 0) \\
38(23 \cdot 2) \\
52(14 \cdot 4)\end{array}$ & $\begin{array}{l}15(19 \cdot 7) \\
15(9 \cdot 1) \\
15(4 \cdot 1)\end{array}$ \\
\hline
\end{tabular}

Study period: 12 months (June to May) (I) 1989-90, (II) 1990-91, (III) 1991-92

Seropositive:

$C$ pneumoniae titre IgG $\geqslant 1 / 16$

$C$ trachomatis titre IgG $\geqslant 1 / 16$

Recent infection (indicative of) fourfold titre change or

$C$ pneumoniae titre IgG $\geqslant 1 / 512$, IgM $\geqslant 1 / 16$

$C$ trachomatis titre IgG $\geqslant 1 / 512$, IgA $\geqslant 1 / 16, \operatorname{IgM} \geqslant 1 / 16$

patients with serological evidence of recent infection $(p<0.05)$.

PREVALENCE OF ANTIBODIES TO $C$ pneumoniae, $C$ trachomatis, $M$ pneumoniae AND Legionella sp A retrospective analysis of our computed laboratory data provided information on 473 $(78 \cdot 6 \%)$ of the patients whose sera were also processed for the detection of antibodies to Legionella sp and M pneumoniae (table 4).

Evidence of recent infection with $C$ trachomatis and $M$ pneumoniae was detected in four and five children, respectively. Recent infection with $C$ peumoniae or Legionella sp was undetectable in children included in our study group.

Sixty three of the 473 patients had antibodies indicative of recent infection with one of the tested groups of antigens. Eight patients had antibodies indicating recent infection with two aetiological agents (six patients with both $C$ pneumoniae and $C$ trachomatis, one patient with both $C$ trachomatis and $M$ pneumoniae, and one patient with both $C$ pneumoniae and Legionella sp).

\section{Discussion}

Prevalence of antibodies to $C$ pneumoniae in the Middle East has not yet been thoroughly investigated. It was therefore of interest to explore this aspect of respiratory infections especially as we were able to analyse the same sera for the prevalence of antibodies to other

Table 4 Prevalence of antibodies to $C$ pneumoniae, $C$ trachomatis, M pneumoniae and Legionella sp in 473 patients

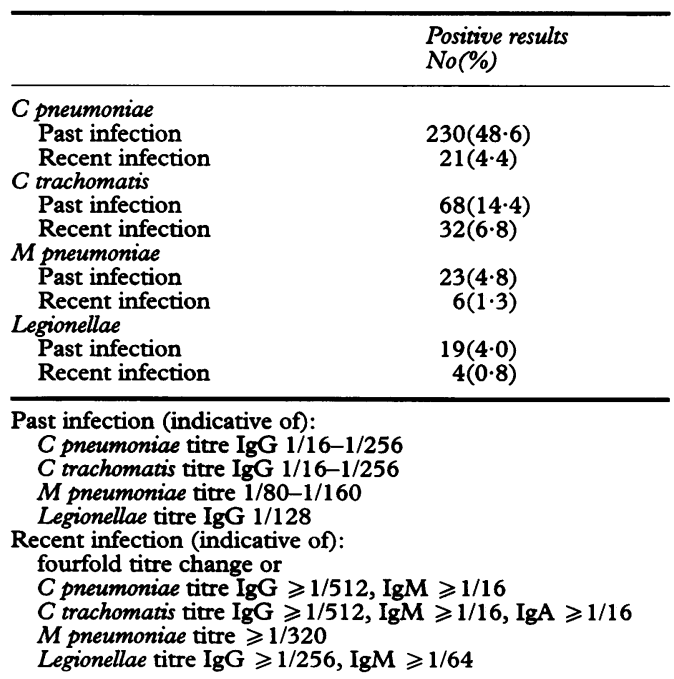

causes of respiratory infections, such as $M$ pneumoniae, Legionella $s p$, and $C$ trachomatis.

The patients included children and adults with acute respiratory diseases attending the Health Center, the casualty Department, or in paediatric or other departments. The overall antibody prevalence to $C$ pneumoniae proved similar to reported values from other parts of the world. ${ }^{24-811-13}$ About half the patients had antibodies to $C$ pneumoniae in their sera, with IgG titres of $1 / 16$ to $\geqslant 1 / 512$. Only $35 \cdot 3 \%$ of the sera positive to $C$ pneumoniae by MIF were positive by the IPAzyme method. IPAzyme is therefore not suitable for the detection of antibodies to $C$ pneumoniae.

Only 21 patients showed evidence of recent infection-in the MIF test (high IgG titre $\geqslant 1$ / 512 , IgM titre of $\geqslant 1 / 16$, or seroconversion)but the limited numbers of paired specimens available in this study must be borne in mind. The need for a larger proportion of patients with available paired sera is obvious, although in only two out of the $18(11 \%)$ patients with paired sera could seroconversion from negative or low positive early serum be shown.

In our study infants under 1 year old showed a relative high prevalence and titre (28\%, MGT 1/52) of anti-TWAR IgG antibodies. This could probably be attributable to transfer of maternal antibodies, as a $50 \%$ prevalence of TWAR antibodies was reported in cord blood. ${ }^{11}$ A 3\% prevalence was reported for Filipino infants under the age of 1 year with acute respiratory infections. ${ }^{4}$

In our study the prevalence of TWAR seropositive children increased with age, from $21 \%$ in the $1-5$ year age group to $33 \%$ in teenagers, but titres were still low (mean geometric titre $1 / 22$ and $1 / 32$, respectively). The reported prevalence of TWAR antibodies in young children (under 10) was relatively low, ranging from $12 \%$ to $25 \%$. The prevalence was much higher in teenagers $(30 \%-76 \%)$ (Shemer-Avni Y, Gonen R, Sarov B, et al. Abstract presented at the 2nd National Scientific Congress on STD, 1992)..$^{21112}$ In our study prevalence increased with age and reached $70 \%$ by old age. Mean titres of $1 / 100$ were measured after the age of 30 . Antibody persistence into old age might be a result of infection and reinfection during life. ${ }^{211-13}$ The incidence and level of antibody titres probably depend on exposure and time elapsed between the last encounter and monitoring for the organism. It is obvious from our results (table 4) that though high antibody prevalence to $C$ pneumoniae, indicating exposure to this organism, was detected in $48 \cdot 6 \%$, only $21(4.4 \%)$ patients had evidence of a recent infection. Although a lower exposure was measured in $14.4 \%$ for $C$ trachomatis, $32(6.8 \%)$ patients had evidence of recent infection.

The decline in prevalence of antibodies to $C$ trachomatis during the study period was significant, and could be attributed, in part, to changes in sexual behaviour, due to AIDS, though our patients were admitted primarily for acute respiratory diseases. A parallel decline in the isolation rate of $C$ trachomatis from the genital tract has been noticed in 
Israel (Ben-Yaakov et al, unpublished data). A similar trend has recently been reported. ${ }^{19}$

When sera react to more than one antigen the question of specificity of each of the detection methods and of cross-reactivity always arises. $^{20-23}$ The MIF test depends mainly on type specific epitopes residing on the major outer membrane protein (MOMP) exposed on the surfaces of elementary bodies, but the use of chlamydial inclusions in the IPAzyme method is based predominantly on a nonspecific genus reaction, presumably involving lipopolysaccharide (LPS) reactivity. As possible cross-reactivity might be caused by the presence of high anti-LPS titres, even the specificity of the MIF assay is debatable. ${ }^{24} 25$ The prevalence of chronic TWAR antibodies in contrast to the relatively low occurrence of $C$ trachomatis antibodies supports those who claim specificity. ${ }^{1}$ Recently serological evidence of infection with $C$ pneumoniae and with at least one other chlamydial species was reported, ${ }^{26}$ as a result of either heterotypic antibodies or mixed related infections.

In our study serological cross-reactivity could not be excluded as only one serum sample was available for most patients.

Infection with more than one respiratory pathogen has been reported by several groups, ${ }^{310}$ while others have not detected such mixed infection. ${ }^{15}$

We detected antibodies to $M$ pneumoniae in $23(4 \cdot 8 \%)$ patients with only six $(1 \cdot 3 \%)$ patients, mostly children, showing evidence of recent infection. Higher prevalences have been reported before. ${ }^{27} 28$

Previous infection with Legionella sp was serologically diagnosed in $4 \%$ of the patients, with $0.8 \%$ showing evidence of recent infection. Cases of legionellosis have been reported in Israel. .9-33 $^{29}$

Our study points to serological evidence of recent infection with $C$ pneumoniae, $M$ pneumoniae, or Legionella sp in $6.5 \%$ (31 out of 473) of our patients. However, the contribution of $C$ trachomatis $(6.8 \%)$ to the diagnosis of respiratory diseases remains inconclusive as in our patients genitourinary infection could not be excluded.

This work was supported, in part, by the Ministry of Absorption, Science Workers Center. We thank Dr K Persson (Section of Virology, Department of Medical Microbiology, University of Lund, Malmo, Sweden), for his gift of $C$ pneumoniae specific monoclonal antibody; Dr R Kazak and $S$ Hoffman for performing the indirect immunofluoresence test for Legionella antibodies; L Sarel for performing the Serodia Myco II test for $M$ pneumoniae antibodies; chief nurse V Reznick and staff for collaboration; Professor I Goldstein Columbia University, USA), for reviewing the manuscript; and Mrs S Zarini for secretarial help.

1 Grayston JT, Kuo CC, Wang SP, Altman J. A new Chlamydia psittaci strain, TWAR, isolated in acute respiratory tract infections. $N$ Engl $\mathcal{F}$ Med 1986;315:161-8.

2 Grayston JT, Wang SP, Kuo CC, Campbell LA. Current knowledge on Chlamydia pneumoniae, strain TWAR, an important cause of pneumonia and other acute respi-
ratory diseases. Eur $\mathcal{f}$ Clin Microbiol Infect Dis 1989; ratory diseases

3 Kleemola M, Saikku P, Visakorpi $R$, et al. Epidemics of pneumonia caused by TWAR, a new Chlamydia organism, in military trainees in Finland. $\mathcal{F}$ Infect Dis 1988; 157:230-6.

4 Saikku $P$, Ruutu $P$, Leinonen $M$, et al. Acute lower-respiraantibody in Filipino children. $\mathcal{F}$ Infect Dis 1988;158 1095-7.
5 Grayston JT, Diwan VK, Cooney M, Wang SP. Community - and hospital - acquired pneumonia associated with Chlamydia TWAR infection demonstrated serologically. Arch Intern Med 1989;149:169-73.

6 Persson $\mathrm{K}$, Trehame J. Diagnosis of infection caused by Chlamydia pneumoniae (strain TWAR) in patients with "Ornithosis" in southern Sweden 1981-1987. Scand $f$ Infect Dis 1989;21:675-9.

7 Persson K. Epidemiological and clinical aspects on infections due to chlamydia pneumoniae (strain TWAR). tions due to chlamydia pneumoniae (stra
Scand $\mathcal{F}$ Infect Dis 1990;(Suppl 69):63-7.

8 Van Renterghem L, Van den Abeele AM, Claeys G, Plum $\mathrm{J}$. Prevalence of antibodies to Chlamydia pneumoniae in a pediatric hospital population in Belgium. Eur $\mathcal{f}$ Clin Microbiol Infect Dis 1990;9:347-9.

9 Bruu AL, Haukens G, Aasen S, et al. Chlamydia pneumoniae infections in Norway 1981-87 earlier diagnosed as ornithosis. Scan f Infect Dis 1991;23:299-304.

10 Chirgwin K, Roblin PM, Gelling M, et al. Infection with Chlamydia pneumoniae in Brooklyn. $\mathcal{F}$ Infect Dis 1991; 163:757-61.

11 Kanamoto Y, Ouchi K, Mizui M, et al. Prevalence of antibody to Chlamydia pneumoniae TWAR in Japan. $f$ Clin Microbiol 1991;29:816-8.

12 Marton A, Karalyi A, Szalka A. Prevalence of Chlamydia pneumoniae antibodies in Hungary. Eur $f$ Clin Microbiol Infect Dis 1992;1:139-42.

13 Stolk-Engelaar MVM, Peeters MF. Seroprevalence of Chlamydia pneumoniae in the normal population. Eur $\mathcal{F}$ Clin Microbiol Infect Dis 1992;11:478.

14 Verkooyen RP, Hazenburg MA, Van Haaren GH, et al. Age-related interference with Chlamydia pneumoniae microimmunofluorescence serology due to circulating rheumatoid factor. $¥$ Clin Microbiol 1992;30:1287-90.

15 Boldur I, Modai D, Iaine A, et al. Legionnaires' disease in Israel: A serological study of hemodialysis patients. Isr $\mathcal{F}$ Med Sci 1982;18:667-70.

16 Wilkinson HW, Farsky CE, Fikes BJ, et al. Measure of immunoglobulin $G, M$ and $A$ specific titers against Legionella pneumophila and inhibition of titers against non specific gram negative bacterial antigens in the indirect immunofluorescence test for Legionellosis. $f$ Clin Microbiol 1979;910:685-9.

17 Barker CE, Sillis M, Wreghitl TG. Evaluation of serodia Myco II particle agglutination test for detecting Mycoplasma pneumoniae antibody: comparison with $\mu$ capture ELISA and indirect immunofluorescence. $₹ \mathrm{Clin}$ Pathol 1990;43:163-5.

18 Hirai Y, Shiode J, Masayoshi T, Kanemasa Y. Application of an indirect immunofluorescence test for detection of Mycoplasma pneumoniae in respiratory exudates. $\mathcal{f}$ Clin Mycoplasma pneumoniae in

19 Samra Z, Day N, Kuffman L, Ketyian D. Prevalence of genital Chlamydia and Mycoplasma infection in Israel. Isr $\mathcal{F}$ Med Sci 1992;28:921

20 Ladany S, Black CM, Farshy CE, et al. Enzyme immunoassay to determine exposure to Chlamydia
pneumoniae (strain TWAR). $\mathcal{F}$ Clin Microbiol 1989;27: 2778-83.

$21 \mathrm{Li} \mathrm{DK}$, Daling JR, Wang SP, Grayston JT. Evidence that Chlamydia pneumoniae, strain TWAR, is not sexually transmitted. $\mathcal{F}$ Infect Dis 1989;160:328-31.

22 Osser S, Persson K. Immune response to genital chlamydial infection and influence of Chlamydia pneumoniae (TWAR) antibodies. Eur $₹$ Clin Microbiol Infect Dis (TWAR) antibodi
1989;8:525-32.

23 Ozanne G, Lefebvre J. Specificity of the microimmunofluorescence assay for the serodiagnosis of Chlamydia pneumoniae infections. Can $\mathcal{F}$ Microbiol 1992;38:1185-9.

24 Schachter J. Human Chlamydia psittaci infection. In: Orie JD, Ridgway G, Schachter J, Taylor-Robinson D, Ward $\mathrm{M}$, eds. Chlamydial infections. Cambridge: Cambridge University Press, 1986:311-20.

25 Wang SP, Grayston JT. Microimmunofluorescence serological studies with the TWAR organism. In: Oriel JD, Ridgway G, Schacter J, Taylor-Robinson D, Ward M, eds. Chlamydial infections. Cambridge: Cambridge eds. Chlamydial infections. C
University Press, 1986:329-32.

26 Thom DH, Grayston JT, Wang SP, et al. Chlamydia pneumoniae strain TWAR, Mycoplasma pneumoniae and viral infections in acute respiratory disease in a university student health clinic population. Am $\mathcal{F}$ Epidemiol 1990; 132:248-56.

27 Lehtomaki K, Leinonen M, Takala A, et al. Etiological diagnosis of pneumonia in military conscripts by combined use of bacterial culture and serological methods. Eur $₹$ Clin Microbiol Infect Dis 1988;7:348--54

28 Sakurai N, Nagayama Y, Honda A, et al. Myocoplasma pneumoniae and other pathogens in the aetiology of lower respiratory tract infections among Japanese children. $\mathcal{f}$ Infect 1988;16:253-61.

29 Aderka D, Garfinkel D, Bograd H, et al. Relapsing Legionella pneumonia. Respiration 1982;43:317-20.

30 Berman J, Loon G, Rubinstein E. Legionnaire's disease. Isr $¥$ Med Sci 1979;15:227-30.

31 Boldur I, Ergaz M, Sompolinsky D. A prevalence study of antibodies to Legionella spp. in geriatric institutions. f Hyg (Camb) 984;92:37-43.

32 Isakov A, Almog CH, Boldur I, et al. Legionnaires' disease: A case acquired in Israel. Isr $\mathcal{f}$ Med Sci 1982;18:873-7.

33 Mundel G, Goldberg A, Boldur I, et al. Legionnaires' disease in Israel: Serological evidence of childhood infection. Isr f Med Sci 1983;19:380-2. 